\title{
Elimination of TSWV from Impatiens hawkerii Bull. and regeneration of virus-free plant
}

\author{
Snežana Milošević ${ }^{1} \cdot$ Angelina Subotić $^{1} \bowtie \cdot$ Aleksandra Bulajić $^{2} \cdot$ Ivana Djekićc $^{2} \cdot$ Sladjana Jevremović $^{1}$ \\ Ana Vučurović ${ }^{2}$. Branka Krstić ${ }^{2}$ \\ 1 Department of Plant Physiology, Institute for Biological Research Siniša Stanković, University of Belgrade, Belgrade, Serbia \\ 2 Department of Phytopathology, Faculty of Agriculture, University of Belgrade, Belgrade- Zemun, Serbia
}

$\triangle$ Corresponding author: subotic.angelina@gmail.com

Received November 20, 2009 / Accepted November 30, 2010

Published online: January 15, 2011

(C) 2011 by Pontificia Universidad Católica de Valparaíso, Chile

\begin{abstract}
The possibility for obtaining virus free plants from Impatiens hawkerii Bull. shoots infected with Tomato spotted wilt virus (TSWV) through meristem-tip culture was examined. TSWV presence in I. hawkerii plants was detected by DAS-ELISA and RT-PCR and identification of the virus was confirmed by sequencing one of the chosen isolate (GenBank Accesion CQ132190). Meristem-tip explants $(0.3-1.5 \mathrm{~mm})$ from virus-infected shoots are cultured on MS media supplemented with different concentrations of the cytokinins, CPPU or TDZ (0.01-1.0 $\mu \mathrm{M})$, respectively. Using this system, a large number of in vitro shoots could be produced from a single explant. Also, cytokinins showed a stimulatory effect on the length, fresh and dry weights of the newly formed shoots. Plant pigments content in I. hawkerii shoots increased significantly in the presence of cytokinins. Rooting of shoots was spontaneous on the same media. Rooted plantlets were transferred to soil where $97 \%$ successfully acclimatized. By DAS-ELISA and RT-PCR, $80 \%$ of the in vitro plantlets were shown to be a virus-free. Considering these, the present protocol seems to be an efficient method for in vitro generation of virus-free $I$. hawkerii plantlets by meristem tip cultures.
\end{abstract}

Keywords: meristem culture, New Guinea Impatiens, Tomato spotted wilt virus, virus- free plants

\section{INTRODUCTION}

In recent years, different strategies have been adopted for the mass propagation of ornamental plant species which could assist breeders to meet customer demands. Some of the popular ornamentals are typically propagated from stem cuttings, one such plant is New Guinea Impatiens (Impatiens hawkerii Bull.), a common potted ornamental. Vegetative propagation is very risky due to the probability of virus transmission to progeny plants (Anderson, 2006; Gera and Zeidan, 2006) and further spread in new production areas via international trade (Brasier, 2008). New Guinea Impatiens plants are especially susceptible to infection with Tomato spotted wilt virus (TSWV), type member of the genus Tospovirus (family Bunyaviridae). TSWV is considered to be widespread, with an extremely broad host-range which includes over 1090 host plants, and is responsible for numerous epidemics with substantial economic losses (Parrella et al. 2003).

I. hawkerii plants infected with TSWV exhibit different symptoms including chlorotic and necrotic spots and rings on leaves as well as necrotic lesions on steams. Symptom appearance and intensity depends on cultivar susceptibility, time of infection, nutritional and environmental conditions, as well as aggressiveness of TSWV isolates (Pappu et al. 2009). Because of the presence of distinctive symptoms, TSWV infected $I$. hawkerii plants are no longer marketable as the demanding ornamentals market requires only symptom less plants.

In Serbia, TSWV infections are on several important host plants such as tobacco, potato, pepper. In 2006 , the production of several popular $I$. hawkerii cultivars grown in private nurseries in Serbia 
suffered substantial losses due to high incidence of TSWV infections. In several nurseries, a high rate of Impatiens mother plants showed local necrotic lesions, chlorotic rings and mosaic, leaf distortion and necrosis as well tip necrosis and plant death. Initial investigations implied that TSWV infections of $I$. hawkerii are frequent and important in Serbia.

This investigation was conducted in order to perform complete identification and partial molecular characterization of virus responsible for observed symptoms and describe protocol for obtaining virusfree plants that could serve as stock material for improving I. hawkerii production.

Tissue culture is an important method of plant regeneration and obtaining disease-free ornamental plants (Faccioli, 2001; Rout et al. 2006). No effective chemical treatments are available for the managing TSWV under greenhouse conditions. Hence, effective elimination of viruses and maintaining of virus-free planting material are important for control of viral disease in plant production. Meristem culture is useful for obtaining virus-free plants from a wide range of important crops (Grout, 1999). The main reason for using meristem-tip culture to eliminate pathogens is due to the fact that many pathogenic organisms fail to invade the meristematic region of shoot tips because the multiplication of cells in meristem is faster than multiplication of pathogens. A second advantage of this type of culture is high genetic stability of regenerated plants with low somaclonal variations, as the clonal propagation takes place without callus interphase. The development of efficient in vitro regeneration method for $I$. hawkerii probably will have strong impacts on new cultivars of this popular ornamental plant.
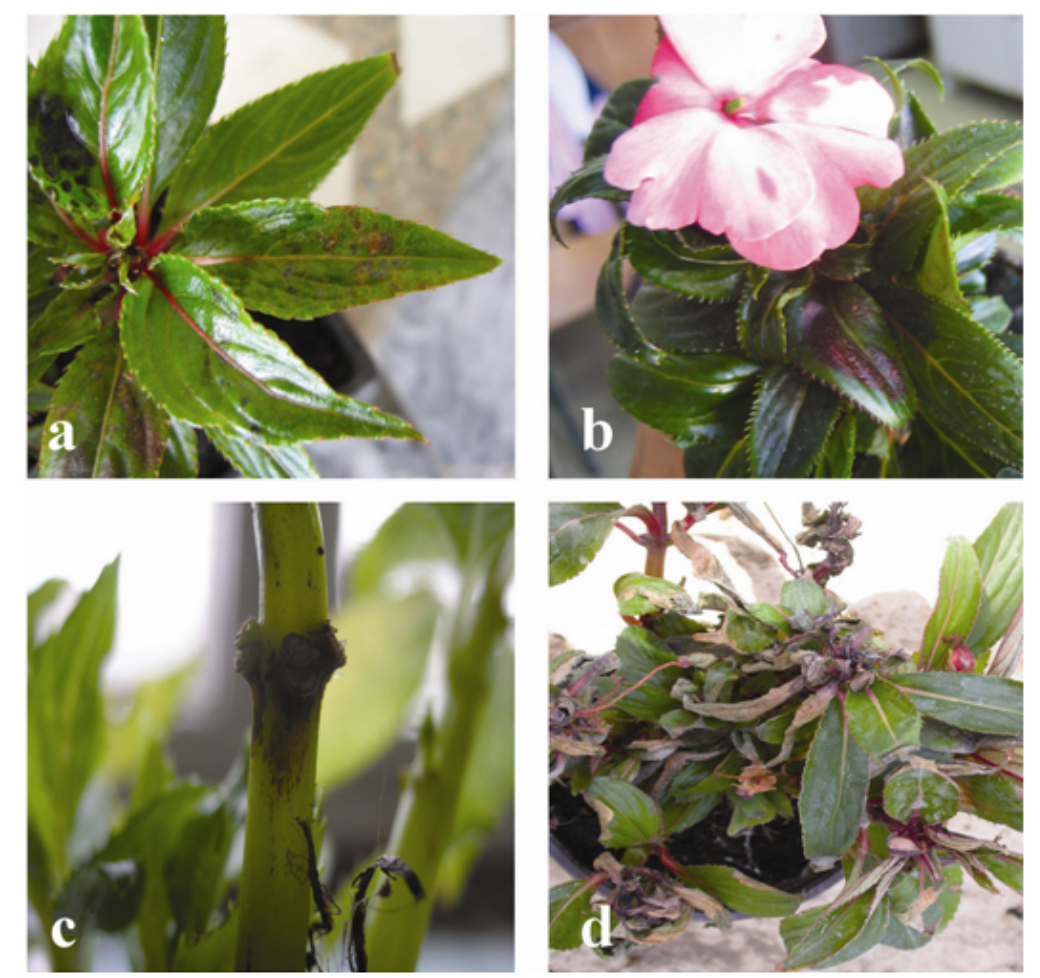

Fig. 1 Symptoms on I. hawkerii Bull. plants infected with TSWV. (a) Speckled necrotic spots and flecks. (b) Flower mottling, and necrotic line pattern of leaf. (c) Brown to black lesions along the stem. (d) Tip necrosis and plant declining.

There have been only two reports on the in vitro propagation of New Guinea Impatiens by conventional methods (Stephens et al. 1985; Han and Stephens, 1987), so far. Many commercial ornamental plants are being propagated by in vitro culture methods in the presence of cytokinins (Preil, 2003). Cytokinins can induce different morphogenetic responses; their effects may differ according to tissue sensitivity to a specific cytokinin and their ability to stimulate cell division in plant meristems (Kurakawa et al. 2007). Synthetic phenylurea derivatives such as TDZ and CPPU have been shown to be most effective for 
organogenesis induction in many species (Tulac et al. 2002; Çöçü et al. 2004; Faisal et al. 2005; Sunagawa et al. 2007). This research was conducted to develop fast and reproducible in vitro protocol for regeneration of $I$. hawkerii virus-free plants. The effects of two cytokinins, CPPU and TDZ on mass propagation and improvement of plant production from the single explant were also evaluated.

\section{MATERIALS AND METHODS}

\section{Source of TSWV-infected I. hawkerii plants}

The experiment was conducted on $I$. hawkerii plants which were kindly supplied by commercial nurseries in Serbia. Plants with symptoms resembling those of TSWV infection were selected for further investigation. From each $I$. hawkerii plant, several samples for serological and molecular detection and identification of the virus were collected from different parts in order to virus detection. Leaves and meristem-tip explants (apical meristem with 1-2 leaf primordia) were chosen for the production of virus-free plants.

\section{TSWV detection and identification}

I. hawkerii plants were tested for the presence of TSWV using a DAS-ELISA kit (Loewe Biochemica, Sauerlach, Germany) and the ELISA procedure was performed according to manufacturer's instructions. Plant tissue samples were extracted in extraction buffer at a rate of 1:10 (wt/vol). After incubation with p-nitrophenyl phosphate (Sigma-Aldrich, St. Louis) at $23^{\circ} \mathrm{C}$ for $1-2 \mathrm{hrs}$ in dark, absorbance at $405 \mathrm{~nm}$ was measured with microplate reader (DASsrl, Italy). Samples were considered positive if the absorbance values were equal to or higher than two times the absorbance of the negative control. Commercial positive controls for TSWV (Loewe) and negative controls (extract from healthy Impatiens leaf tissue, commercially avaliable negative control from Loewe and extraction buffer) were included in each ELISA test.

Virus molecular detection was conducted by RT-PCR using previously developed primer pairL1 TSWVR (5'-AATTGCCTTGCAACCAATTC) and L2 TSWVF (5'-ATCAGTCGAAAT GGTCGGCA) (Mumford et al. 1994). Complete identification was performed by sequencing of obtained PCR product and comparing its derived sequence with sequences available in National Center of Biotechnology Information (NCBI) (http://www.ncbi.nim.nih.gov/BLAST/). RT-PCR was used for detection of the virus presence in plantlets obtained by meristem-tip culturing from infected $I$. hawkerii Bull. as well.

Table 1. Effect of CPPU and TDZ on axillary shoots multiplication, shoot length, fresh and dry mass of $I$. hawkerii.

\begin{tabular}{|c|c|c|c|c|c|}
\hline $\begin{array}{c}\text { CPPU } \\
\mu \mathrm{M}\end{array}$ & $\begin{array}{c}\text { TDZ } \\
\mu M\end{array}$ & $\begin{array}{l}\text { Average } \\
\text { number of } \\
\text { shoots }\end{array}$ & $\begin{array}{l}\text { Average } \\
\text { shoot length } \\
\text { (cm) }\end{array}$ & $\begin{array}{c}\text { Shoot fresh mass } \\
\text { FW } \\
{\left[\text { g plant }^{-1}\right]}\end{array}$ & $\begin{array}{l}\text { Shoot dry } \\
\text { mass DW } \\
\text { [g plant }{ }^{-1} \text { ] }\end{array}$ \\
\hline- & - & $1.42 a^{*}$ & $1.63 \pm 0.036 b$ & $1.14 \pm 0.114 a$ & $0.08 \pm 0.008 a$ \\
\hline 0.01 & - & $7.3 f$ & $2.53 \pm 0.061 d$ & $2.05 \pm 0.260 c$ & $0.17 \pm 0.017 b$ \\
\hline 0.1 & - & $4.98 \mathrm{e}$ & $2.05 \pm 0.054 c$ & $1.86 \pm 0.125 c$ & $0.17 \pm 0.011 b$ \\
\hline 1.0 & - & $3.45 d$ & $1.32 \pm 0.020 b$ & $0.80 \pm 0.069 a$ & $0.09 \pm 0.008 a$ \\
\hline- & 0.01 & $3.25 d$ & $1.90 \pm 0.036 c$ & $2.45 \pm 0.318 b$ & $0.16 \pm 0.012 b$ \\
\hline- & 0.1 & $2.58 \mathrm{c}$ & $1.32 \pm 0.019 b$ & $1.27 \pm 0.163 b$ & $0.08 \pm 0.007 a$ \\
\hline- & 1.0 & $1.94 b$ & $1.04 \pm 0.020 a$ & $1.44 \pm 0.112 a$ & $0.08 \pm 0.006 a$ \\
\hline
\end{tabular}

*Data present mean value \pm standard error. The numbers with the same letters are not significant at the level of $1 \%$ (LSD test). 
Total RNA was extracted from freeze-dried leaves of symptomatic source plants, as well as from in vitro produced I. hawkerii plants using the RNeasy Plant Mini Kit (Qiagen, Hilden, Germany) following the manufacturer's instructions. Tissue sample from healthy I. hawkerii leaves was used as a negative control in RNA extraction and RT-PCR amplification. Specific nucleotide sequence of TSWV partial L gene coding for RNA-dependent RNA polymerase, was detected using RT-PCR with previously developed protocol and specific primers L1 TSWVR and L2 TSWVF (Mumford et al. 1994). RT-PCR was carried out with the OneStep RT PCR kit (Qiagen, Hilden, Germany), according to the manufacturer's instruction and performed in a thermal cycler (Biometra, T-1 Termocycler). The RTPCR reaction mixture included $400 \mu \mathrm{M}$ each of the four dNTPs, $0,6 \mu \mathrm{M}$ each primer and $1 \mu$ l extracted RNA in a final volume of $25 \mu \mathrm{l}$. Cycling conditions were as follows: applying $30 \mathrm{~min}$ at $50^{\circ} \mathrm{C}$ for reverse transcription, and 40 cycles of $1 \mathrm{~min}\left(15 \mathrm{~min}\right.$ for the first cycle) at $94^{\circ} \mathrm{C}$ for denaturation step, $1 \mathrm{~min}$ at $37^{\circ} \mathrm{C}$ for annealing, and $1 \mathrm{~min}\left(10 \mathrm{~min}\right.$ for the last cycle) at $72^{\circ} \mathrm{C}$ for primer extension (35 cycles). Amplified products were analysed by $1 \%$ agarose gel electrophoresis, stained with ethidium bromide and visualised under a UV transilluminator. The amplification product of predicted size, obtained using L1 TSWVR/ L2 TSWVF primers, derived from the isolate 52-06 was sequenced directly after the purification with QUIAqick PCR Purification Kit (Qiagen). Sequencing was performed on an automated equipment (BMR Genomics, Padova, Italy) using both primers. The nucleotide sequence of the amplification product was deposited in the GenBank and compared with those of previously reported TSWV isolates which were retrived online from the NCBI.
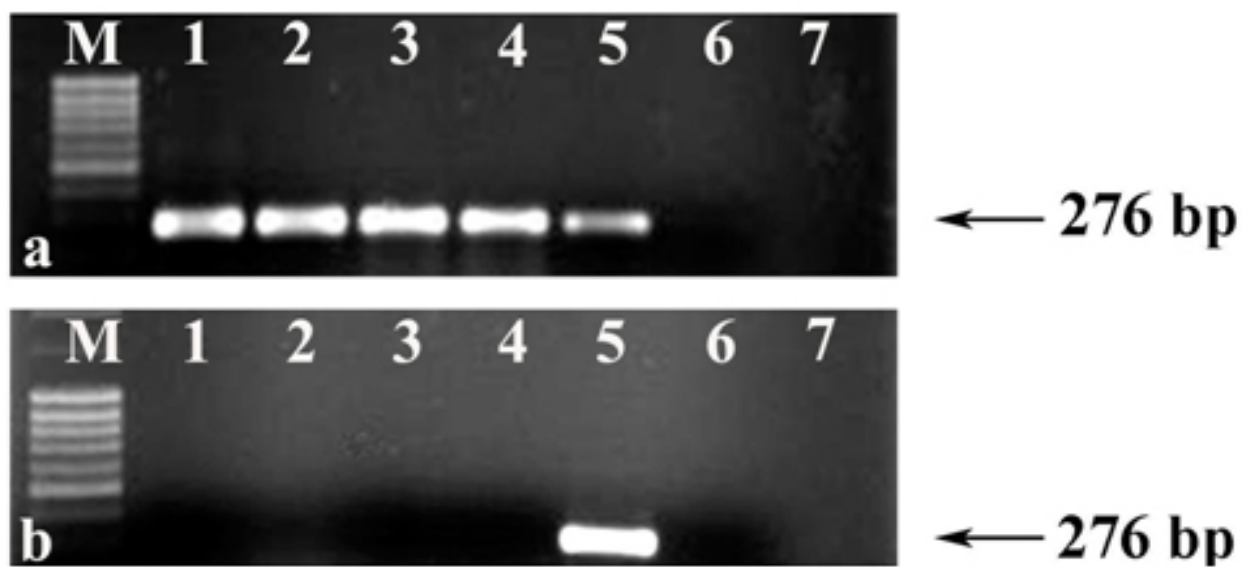

Fig. 2 Detection of TSWV $\mathrm{L}$ gene by RT-PCR with primers L1 TSWV/L2 TSWV. (a) RT-PCR products showing 276 bp amplicon in naturally infected $I$. hawkerii. (b) After elimination of virus. Lane M, MassRuler DNA ladder, Low Range (Fermentas Life Sciences GmbH, Lithuania); lanes 1 to 4, samples; lane 5, positive control; lane 6, negative control, Rnase free water instead target RNA; lane 7 - negative control, healthy I. hawkerii plants.

\section{Establishment of virus-free I. hawkerii plants by meristem-tip culture}

Shoot tips of naturally infected $I$. hawkerii Bull. plants were washed thoroughly under running tap water and surface sterilized with sodium hypochlorite solution $(10 \%)$ for $15 \mathrm{~min}$. Treated explants were washed 4-5 times with sterile distilled water to remove the effect of sterilizing agent. The meristem tips 0.3-1.5 $\mathrm{mm}$ in length were cut from nodal segments under a binocular microscope. Leaves are removed one by one until the meristem dome is visible, but still partially covered by 1-2 young leaf primordia. The explants were cultured onto solid MS basal salt media (Murashige and Skoog, 1962) with $30 \mathrm{~g} \mathrm{l}^{-1}$ sucrose and $7.0 \mathrm{~g} \mathrm{I}^{-1}$ agar. After four weeks, developed virus-free shoots were subcultured on MS media for multiplication supplemented with different concentrations of CPPU or TDZ (0.1-1.0 $\mu \mathrm{M})$, respectively and the each treatment was replicated ten times and repeated three times. After 4 weeks in culture, the number, length, fresh weight (FW) and dry weight (DW) of shoots, as well as number and root length produced by each explants were recorded. This correlation could also be used for approximately calculate the number of shoots that could be regenerated from one explant during certain period of time. Data were analyzed for significant differences using one-way analysis of variance (ANOVA) and means were separated using (LSD) individual error rate at the 5\% significant level using StatGrafics software version 4.2 (STSC Inc., Rockville, Maryland, USA). The formed shoots 
were subsequently transferred to hormone-free MS medium for shoot elongation and rooting. The $\mathrm{pH}$ of the medium was adjusted to 5.8 before autoclaving at $\left(114^{\circ} \mathrm{C}\right)$ for 20 min (AES-75, RAYPA, Spain). Cultures were maintained in a growth chamber (Termovent, Belgrade, Serbia) at $25 \pm 2{ }^{\circ} \mathrm{C}$ under $16 / 8$ hrs (light/dark) photoperiod with a light intensity of approximately, $30-40 \mu \mathrm{mol} \mathrm{m} \mathrm{m}^{-2} \mathrm{~s}^{-1}$, supplied coolwhite fluorescent lamps. The rooted plantlets were taken out of the culture vessels after 3-4 weeks, delicately washed under running tap water to remove the adhering culture medium from the roots, and then transferred to pots $(\varnothing 10)$ containing potting mixture in greenhouse conditions.

\section{Photosynthetic pigments estimation}

Contents of Chlorophyll a $(\mathrm{Chl} a)$, Chlorophyll $b(\mathrm{Chl} b)$ and total carotenoids were spectrophotometrically measured following the method of Wellburn (1994). After 4 weeks in culture, the leaves with similar age were taken to extract the pigments. For measurement about $0.5 \mathrm{~g}$ of mature leaves were extracted in $10 \mathrm{ml} 80 \%(\mathrm{v} / \mathrm{v})$ cold aqueous acetone. The extract was centrifuged at 2000 rpm for $10 \mathrm{~min}$, the supernatant was diluted in $80 \%$ aqueous acetone for spectrophotometric measurements. The absorbance was determined using a spectrophotometer (Agilent 8453, USA) with wavelengths at $663 \mathrm{~nm}(\mathrm{Chl} \mathrm{a}), 646 \mathrm{~nm}(\mathrm{Chl} b)$ and $470 \mathrm{~nm}$ (carotenoids).

\section{RESULTS AND DISCUSSION}

\section{TSWV detection and identification in naturally infected $I$. hawkerii plants}

From several private commercial nurseries in Serbia, total of $105 \mathrm{l}$. hawkerii plants with symptoms resembling those of TSWV infection were collected and tested by DAS-ELISA. Observed symptoms included range of speckled necrotic spots and flecks, leaf bronzing, flowers discoloration, as well as necrotic mottle and brown to black streaks of steam and occasional whole plant declining (Figure 1). Through DAS-ELISA analyses revealed that TSWV infection rate in symptomatic $I$. hawkerii plants was $75.24 \%$ (79/105). The presence of another important Impatiens infecting Tospovirus, Impatiens necrotic spot virus (INSV) was not detected in collected plants (data not shown). All infected $I$. hawkerii were maintained in an insect proof greenhouse. Presence of TSWV in all chosen mother plants was additionally confirmed through RT-PCR.

None of the DAS-ELISA negative I. hawkerii plants tested positive in RT-PCR. No amplification was obtained from symptomless and healthy Impatiens plants which were used as negative controls (Figure 2a). One of the obtained TSWV isolates, designated as 52-06 was selected for sequencing. The obtained sequence (GenBank Accesion CQ132190) was 91 to $100 \%$ identical at the nucleotide level with TSWV sequences from other parts of the world, and showed $100 \%$ homology with Serbian isolates 39-06 and 603-07 from tobacco and tomato respectively (GenBank Accesion FJ189393 and CQ279732) and were the most distant (90.07\%) from the Salabinata isolate from hot pepper from Indonesia (GenBank Accesion FJ177302).

\section{TSWV indexing in meristem-tip culture obtained $I$. hawkerii}

I. hawkerii plantlets obtained by meristem-tip culture were tested through DAS-ELISA and RT-PCR. Using both detection methods, $80 \%$ of obtained $I$. hawkerii were virus-free (Figure $2 \mathrm{~b}$ ). A relatively small rate $(12 \%)$ of plants in which TSWV could not be eliminated were symptomless, but with virus concentration high enough to be detected through DAS-ELISA. Probably, high virus concentration in $I$. hawkerii is related to substantial susceptibility of tested plant genotypes. Nevertheless, RT-PCR, which is believed to be more sensitive and capable of detecting significantly lower quantities of target virus should be included for further commercial production of virus-free $I$. hawkerii plants, especially with cultivars exhibiting TSWV resistance and accumulating lower TSWV titers.

The high rate of TSWV elimination from infected I. hawkerii plants confirmed by reliable, sensitive and specific tests utilized in this investigation, demonstrates that meristem-tip culture provides successful way of obtaining virus-free plants. Described protocol of virus elimination proved to be efficient and recommendable technique that could be applied in a large scale $I$. hawkerii production. 
Table 2. Changes in the content of pigments of $I$. hawkerii leaves.

\begin{tabular}{|c|c|c|c|c|c|c|c|c|}
\hline $\begin{array}{l}\text { CPPU } \\
\mu \mathrm{M}\end{array}$ & $\begin{array}{l}\text { TDZ } \\
\mu \mathrm{M}\end{array}$ & $\begin{array}{l}\text { Chlorophyll a [mg } \\
\left.g^{-1}(\mathrm{fw})\right]\end{array}$ & $\begin{array}{l}\text { Chlorophyll b } \\
{\left[\mathrm{mg} \mathrm{g}^{-1}(\mathrm{fw})\right]}\end{array}$ & $\begin{array}{l}\text { Carotenoids } \\
{\left[\mathrm{mg} \mathrm{g}^{-1}(\mathrm{fw})\right]}\end{array}$ & $\begin{array}{l}\text { Total pigments } \\
{\left[\mathrm{mg} \mathrm{g}^{-1}(\mathrm{fw})\right]}\end{array}$ & $\begin{array}{l}\text { Chlorophyll content } \\
\quad(\mathrm{Chl} \mathrm{a}+\mathrm{Chl} \mathrm{b})\end{array}$ & $\begin{array}{c}\text { Chlorophylls } \\
\text { ratio } \\
\text { (Chl a/Chl b) }\end{array}$ & $\begin{array}{l}\text { Carotenoid and } \\
\text { chlorophyll ratio }\end{array}$ \\
\hline \multicolumn{2}{|c|}{ Control plants } & $0.76 \pm 0.01 \mathrm{~cd}^{*}$ & $0.32 \pm 0.01 \mathrm{~cd}$ & $0.15 \pm 0.03 d$ & $1.23 \pm 0.05 \mathrm{~cd}$ & $1.08 \pm 0.02 \mathrm{~cd}$ & $2.34 a b$ & $0.14 a b c$ \\
\hline 0.01 & - & $0.70 \pm 0.04 c$ & $0.29 \pm 0.03 c$ & $0.14 \pm 0.01 \mathrm{~cd}$ & $1.13 \pm 0.08 c$ & $0.99 \pm 0.07 c$ & $2.53 a b$ & $0.15 b c$ \\
\hline 0.1 & - & $0.78 \pm 0.01 \mathrm{~cd}$ & $0.35 \pm 0.03 \mathrm{~cd}$ & $0.13 \pm 0.01 \mathrm{~cd}$ & $1.26 \pm 0.03 c d$ & $1.13 \pm 0.04 d$ & $2.30 a b$ & $0.12 a$ \\
\hline 1.0 & - & $0.60 \pm 0.03 b$ & $0.19 \pm 0.01 b$ & $0.13 \pm 0.01 \mathrm{~cd}$ & $0.92 \pm 0.05 b$ & $0.79 \pm 0.05 c$ & $3.15 c$ & $0.17 c$ \\
\hline- & 0.01 & $0.76 \pm 0.02 \mathrm{~cd}$ & $0.32 \pm 0.02 \mathrm{~cd}$ & $0.14 \pm 0.01 \mathrm{~cd}$ & $1.22 \pm 0.03 \mathrm{~cd}$ & $1.08 \pm 0.04 \mathrm{~cd}$ & $2.38 a b$ & $0.13 a b$ \\
\hline- & 0.1 & $0.80 \pm 0.04 \mathrm{~cd}$ & $0.37 \pm 0.02 d$ & $0.14 \pm 0.02 \mathrm{~cd}$ & $1.31 \pm 0.07 d$ & $1.17 \pm 0.06 d$ & $2.18 a$ & $0.12 \mathrm{ab}$ \\
\hline- & 1.0 & $0.56 \pm 0.04 b$ & $0.19 \pm 0.02 b$ & $0.12 \pm 0.01 b$ & $0.87 \pm 0.06 b$ & $0.75 \pm 0.06 b$ & $2.99 c$ & $0.16 c$ \\
\hline \multicolumn{2}{|c|}{ Seedling } & $0.18 \pm 0.01 \mathrm{a}$ & $0.06 \pm 0.00 a$ & $0.06 \pm 0.01 a$ & $0.30 \pm 0.01 a$ & $0.24 \pm 0.01 a$ & $2.94 \mathrm{bc}$ & $0.25 d$ \\
\hline \multicolumn{2}{|c|}{ Infected plants } & $0.14 \pm 0.01 a$ & $0.03 \pm 0.01 a$ & $0.05 \pm 0.01 a$ & $0.22 \pm 0.01 a$ & $0.17 \pm 0.02 a$ & $5.61 d$ & $0.26 \mathrm{~d}$ \\
\hline
\end{tabular}




\section{Establishment of virus-free I. hawkerii plants by meristem-tip culture}

The meristem-tip explants (486) were excised from naturally infected $I$. hawkerii plants infected with TSWV (confirmed by RT-PCR) and used for establishment of virus-free plants. Some explants were lost as a result of bacterial and fungal contaminations. Explant contaminations in culture ranged from $7.2 \%$ to $9.8 \%$. The explants cultured on a MS media were characterized by initial enlargement of the existing apical meristems and shoot sprouting at 2-3 weeks post culture initiation (Figure 3a). Development of healthy explants was rapid. The majority of the remaining meristems (89\%) grew satisfactorily and established shoots after 4 weeks in culture. Meristem-tip culture has been used widely for the production of virus-free plant in chrysanthemums propagated by vegetative means (Verma et al. 2004; Kumar et al. 2009). Transfer of apical meristem with one or two leaf primordia to a culture medium and its regeneration into healthy plants may lead to the elimination of a virus.

The in vitro regeneration of $I$. hawkerii from explants grown on the MS medium supplemented with different cytokinins at varying concentrations is presented in Table 1. All concentrations of CPPU and TDZ facilitated axillary shoot differentiation, but CPPU was more efficient that TDZ, efficiency was measured in terms of average number of shoots, average shoot length, shoot fresh and dry mass. Among the various concentrations of CPPU and TDZ tested, $0.01 \mathrm{CPPU}$ produced the highest number of shoots (7.3). Shoot elongation was inhibited as cytokinins concentration increased (Table 1). The fewest but longest shoots were stimulated with CPPU at $0.01 \mu \mathrm{M}$ (Figure 3c). Micropropagation of $I$. hawkerii Bull. has been reported by culturing shoot tips which yielded very few shoots (Han and Stephens, 1987).
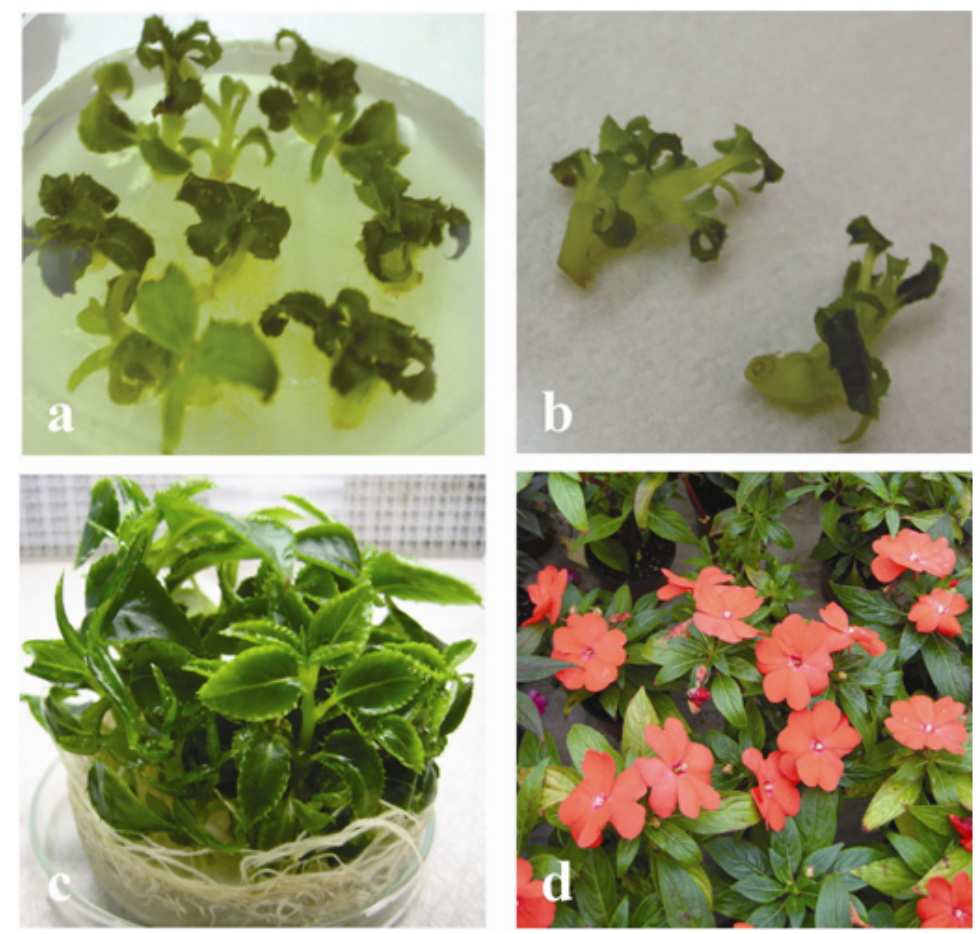

Fig. 3 In vitro propagation of virus-free $\boldsymbol{I}$. hawkerii Bull. (a) Shoot formation on MS medium after culturing for 2 weeks. (b) Hyperhydric shoots developed on medium with $1.0 \mu \mathrm{M}$ TDZ. (c) Well developed in vitro plantlets after 4 weeks of culture on the medium with $0.01 \mu \mathrm{M}$ CPPU. (d) Acclimatized plants maintained under greenhouse conditions.

The results showed that CPPU and TDZ caused an increase in fresh weight and decrease in dry weight of in vitro shoots. The higher fresh mass of axillary shoots in correlation with lower dry mass was probably a consequence of vitrification observed during in vitro propagation on media with cytokinins (Ziv, 1991). In our experiments visible vitrification was observed at all tested concentrations 
of TDZ (Figure 3b). In many plant species the special conditions during in vitro culture results in the formation plantlets with atypical morpho-physiology traits (Hazarika, 2006). However, in our experiments the shoot regenerated from explants, which had been cultured on the media supplemented with CCPU was healthy and normal. The effectiveness of CPPU in organogenesis has been well documented in I. walleriana (Subotić et al. 2008). High frequency rooting activity was found during shoot multiplication, except in the presence of high concentration of both cytokinins. High levels of spontaneous rooting were observed in $I$. hawkerii during propagation (Figure $3 \mathrm{~d}$ ), this was also observed in mulberry (Lu, 2002). Recently TDZ has become an integral component in tissue culture of many species (Mithila et al. 2003; Landi and Mezzetti, 2006). TDZ has both auxin- and cytokinin-like roles in induction of in vitro morphogenesis (Singh et al. 2003). The vitrification of shoots and foliar deformation of $I$. hawkerii are noticed at all tested concentrations of TDZ. In the light of these results we do not recommend the use TDZ for micropropagation of $I$. hawkerii. The importance of this finding is that by choosing the right cytokinin in optimal concentration, the formation of axillary shoots in $l$. hawkerii can be substantially increased.

Photosynthesis is affected by many biotic stresses (Synková et al. 2006). Therefore, changes in photosynthethic pigment contents provide a convenient model for studying the responses of $I$. hawkerii plants to virus infection. There are no data in the literature indicating the effect of TSWV on photosynthetic reactions. TSWV infection reduced $\mathrm{Chl} a, \mathrm{Chl} b$ and carotenoids to $1 / 5.4,1 / 10.6$ and $1 / 3.0$ levels of the control plants, respectively. Also, infection by this virus showed a decrease in total pigment content to1/5.6 level as compared to that of the control (Table 2). TSWV induced significant reduction in $\mathrm{Chl} b$ and increase in ratio $\mathrm{Chl} a / \mathrm{Chl} b$ (Table 2). These changes suggest a damage of light harvesting pigments-protein complexes of thylakoid membrane. The decrease in chlorophyll content $(\mathrm{Chl} \mathrm{a}+\mathrm{Chl} b)$ coupled with lower concentrations of carotenoids in infected leaves suggested a loss in the defense mechanism of plants against oxidative stress induced by the virus. The negative effects of viral and bacterial pathogens on the rate of photosynthesis were also reported by many other authors (Bertamini et al. 2002; Akhkha et al. 2003; Arias et al. 2003). Both CPPU and TDZ depending on the concentrations applied, either stimulated or inhibited photosynthetic pigment content. However, at concentrations equimolar to that of $0.1 \mu \mathrm{M} \mathrm{CPPU}$ and TDZ the pigment content decreased (Table 2). The application of higher concentrations of the cytokinins $(1.0 \mu \mathrm{M})$ caused an increase in the ratio between the two kinds of chlorophyll. The increase in the $\mathrm{Chl} \mathrm{a/Chl} b$ ratio is the result of a decrease in the amount of $\mathrm{Chl} b$ produced in the response to CPPU and TDZ treatments at higher concentration. However, other authors have suggested that the inversion in $\mathrm{Chl} a / \mathrm{Chl} b$ ratio may be due to vitrification (Hazarika, 2006). These results give some additional information about the effects of phenylurea cytokinins on growth and pigments content of in vitro I. hawkerii shoot cultures. The results observed in this paper are of immense practical importance and also highlight the usefulness of cytokinins for in vitro mass production of I. hawkerii.

In this study, TSWV was successfully eliminated from naturally infected $I$. hawkerii plants by using meristem-tip culture. Considering difficulties for virus control and substantial economic impacts on production of different host plants, obtaining virus-free mother plants to TSWV provides a feasible control strategy. Further research towards improving the resistance level by our suggested protocol for obtaining large number of genetically uniform virus-free $I$. hawkerii will have significant impacts on ornamentals production. This protocol for successful TSWV elimination and obtaining virus-free $I$. hawkerii plants could be an effective way for flower crops producer to avoid the losses caused by the virus. The present study is an efficient in vitro protocol for virus elimination combined with highly sensitive diagnostic technique ensures the commercial large scale production of virus-free I. hawkerii plants. The developed protocol for obtaining substantial rate of virus-free shoots of $I$. hawkerii also provides us the base for further studies of various specific ways for virus elimination using different techniques including cryotherapy and genetic engineering.

Financial support: This study was supported by the Serbian Ministry of Science and Technological Development (Project NºTR-31019).

\section{REFERENCES}

AKHKHA, A.; CLARKE, D.D. and DOMINY, P.J. (2003). Relative tolerances of wild and cultivated barley to infection by Blumeria graminis f. sp. hordei (Syn. Erysiphe graminis f. sp. hordei). II - the effects of infection on photosynthesis and respiration. Physiological and Molecular Plant Pathology, vol. 62, no. 6, p. 347-354. [CrossRef] 
ANDERSON, N.O. (2006). Flower breeding and genetics: Issues, challenges and opportunities for $21^{\text {st }}$ Century. Berlin, Springer-Verlag, 822 p. ISBN 1402044275.

ARIAS, M.C.; LENARDON, S. and TALEISNIK, E. (2003). Carbon metabolism alterations in sunflower plants infected with the sunflower chlorotic mottle virus. Journal of Phytopathogy, vol. 151, no. 5, p. 267-273. [CrossRef]

BERTAMINI, M.; NEDUNCHEZHIAN, N.; TOMASI, F. and GRANDO, M.S. (2002). Phytoplasma [Stolbur-subgroup (Bois Noir-BN)] infection inhibits photosynthetic pigments, ribulose-1,5-bisphosphate carboxylase and photosynthetic activities in field grown grapevine (Vitis vinifera L. cv. Chardonnay) leaves. Physiology and Molecular Plant Pathology, vol. 61, no. 6, p. 357-366. [CrossRef]

BRASIER, C.M. (2008). The biosecurity threat to the UK and global environment from international trade in plants. Plant Pathology, vol. 57, no. 5, p. 792-808. [CrossRef]

ÇÖÇÜ, S.; URANBEY, S.; IPEK, A.; KHAWAR, K.M.; SARIHAN, E.O.; KAYA, M.D.; PARMAKSIZ, İ. and ÖZCAN, S. (2004). Adventitious shoot regeneration and micropropagation in Calendula officinalis L. Biologia Plantarum, vol. 48, no. 3, p. 449-451. [CrossRef]

FACCIOLI, G. (2001). Control of potato viruses using meristem and stem-cutting cultures, thermotherapy and chemotherapy. In: LOEBENSTEIN, G.; BERGER, H.P.; BRUNT, A.A. and LAWSON, R.G. eds. Virus and Virus-Like Diseases of Potatoes and Production of Seed Potatoes. Dordrecht, The Netherlands, Kluwer Academic Publisher, p. 365-390.

FAISAL, M.; AHMAD, N. and ANIS, M. (2005). Shoot multiplication in Rauvolfia tetraphylla L. using thidiazuron. Plant Cell, Tissue and Organ Culture, vol. 80, no. 2, p. 187-190. [CrossRef]

GERA, A and ZEIDAN, M. (2006). New and emerging virus diseases in ornamental crops. Acta Horticulturae, 722, p. $175-180$.

GROUT, B.W.W. (1999). Meristem-tip culture for propagation and virus elimination. In: HALL, R.D. ed. Methods in Molecular Biology, vol. 111, Plant Cell Culture Protocols. Totowa, NJ, Humana Press, p. 115-125.

HAN, K. and STEPHENS, L.C. (1987). Growth regulators affect in vitro propagation of two interspecific Impatients hybrids. Scientia Horticulturae, vol. 32, no. 3-4, p. 307-313. [CrossRef]

HAZARIKA, B.N. (2006). Morpho-physiological disorders in in vitro culture of plants. Scientia Horticulturae, vol. 108, no. 2, p. 105-120. [CrossRef]

KUMAR, S.; KHAN, M.S.; RAJ, S.K. and SHARMA, A.K. (2009). Elimination of mixed infection of Cucumber mosaic and Tomato aspermy virus from Chrysanthemum morifolium Ramat. cv. Pooja by shoot meristem culture. Scientia Horticulturae, vol. 119, no. 2, p. 108-112. [CrossRef]

KURAKAWA, T.; UEDA, N.; MAEKAWA, M.; KOBAYASHI, K.; KOJIMA, M.; NAGATO, Y.; SAKAKIBARA, H. and KYOZUKA, J. (2007). Direct control of shoot meristem activity by a cytokinin-activating enzyme. Nature, vol. 445, no. 7128, p. 652-655. [CrossRef]

LANDI, L. and MEZZETTI, B. (2006). TDZ, auxin and genotype effects on leaf organogenesis in Fragaria. Plant Cell Reports, vol. 25, no. 4, p. 281-288. [CrossRef]

LU, M.C. (2002). Micropropagation of Morus latifolia Poilet using axillary buds from mature trees. Scientia Horticulturae, vol. 96, no. 1-4, p. 329-341. [CrossRef]

MITHILA, J.; HALL, J.; VICTOR, J.M.R. and SAXENA, P. (2003). Thidiazuron induces shoot organogenesis at low concentrations and somatic embryogenesis at high concentrations on leaf and petiole explants of African violet (Saintpaulia ionantha Wendl.). Plant Cell Reports, vol. 21, no. 5, p. 408-414. [CrossRef]

MUMFORD, R.A.; BARKER, I. and WOOD, K.R. (1994). The detection of tomato spotted wilt virus using the polymerase chain reaction. Journal of Virological Methods, vol. 46, no. 3, p. 303-311. [CrossRef]

MURASHIGE, T. and SKOOG, F. (1962). A revised medium for rapid growth and bioassays with tobacco tissue culture. Physiologia Plantarum, vol. 15, no. 3, p. 473-497. [CrossRef]

PAPPU, H.R.; JONES, R.A.C. and JAIN, R.K. (2009). Global status of tospovirus epidemics in diverse cropping systems: Successes achieved and challenges ahead. Virus Research, vol. 141, no. 2, p. 219-236. [CrossRef]

PARRELLA, G.; GOGNALONS, P.; GEBRE-SELASSIÉ, K.; VOVLAS, C. and MARCHOUX, G. (2003). An update of the host range of Tomato spotted wilt virus. Journal of Plant Pathology, vol. 85, no. 4 (Special issue), p. 227264.

PREIL, W. (2003). Micropropagation of ornamental plants. In: Laimer, M. and Rucker, W. eds. Plant Tissue Culture 100 Years Since Gottlieb Haberlandt. Wien, Springer Verlag, p. 115-133.

ROUT, G.R.; MOHAPATRA, A. and JAIN, S.M. (2006). Tissue culture of ornamental pot plant: A critical review on present scenario and future prospects. Biotechnology Advances, vol. 24, no. 6, p. 531-560. [CrossRef]

SINGH, N.D.; SAHOO, L.; SARIN, N.B. and JAIWAL, P.K. (2003). The effect of TDZ on organogenesis and somatic embryogenesis in pigeonpea (Cajanus cajan L. Millsp). Plant Science, vol. 164, no. 3, p. 341-347. [CrossRef]

SUBOTIĆ, A.; JEVREMOVIĆ, S.; CINGEL, A. and MILOŠEVIĆ, S. (2008). Effect of urea - type citokinins on axillary shoots regeneration of Impatiens walleriana L. Biotechnology and Biotechnological Equipment, vol. 22, no. 3, p. 817-819.

SUNAGAWA, H.; AGARIE, S.; UMEMOTO, M.; MAKISHI, Y. and NOSE, A. (2007). Effect of urea-type cytokinins on the adventitious shoots regeneration from cotyledonary node explant in the common ice plant, Mesembryanthemum crystallinum. Plant Production Science, vol. 10, no. 1, p. 47-56. [CrossRef]

STEPHENS, L.C.; KRELL, S.L. and WEIGLE, J.L. (1985). In vitro-propagation of Java, New Guinea, and Java-xNew Guinea Impatiens. HortScience, vol. 20, no. 3, p. 362-363.

SYNKOVÁ, H.; SEMORÁDOVÁ, Š.; SCHNABLOVÁ, R.; MÜLLER, K.; POSPÍŠILOVÁ, J.; RYŠLAVÁ, H.; MALBECK, J. and ČEŘOVSKÁ, N. (2006). Effects of biotic stress caused by Potato virus $Y$ on photosynthesis in ipt transgenic and control Nicotiana tabacum L. Plant Science, vol. 171, no. 5, p. 607-616. [CrossRef] 
TULAC, S.; LEJAK-LEVANIC, D.; KRSNIK-RASOL, M. and JELASKA, S. (2002). Effect of BAP, TDZ and CPPU on multiple shoot formation in pea (Pisum sativum L.) in culture in vitro. Acta Biologica Cracovensia Series Botanica, vol. 44, p. 161-168.

VERMA, N.; RAM, R.; HALLAN, V.; KUMAR, K. and ZAIDI, A.A. (2004). Production of Cucumber mosaic virus-free chrysanthemums by meristem tip culture. Crop Protection, vol. 23, no. 5, p. 469-473. [CrossRef]

WELLBURN, A.R. (1994). The spectral determination of chlorophylls a and b, as well as total carotenoids, using various solvents with spectrophotometers of different resolution. Journal of Plant Physiology, vol. 144, no. 3, p. 307-313.

ZIV, M. (1991). Quality of micropropagated plants - Vitrification. In Vitro Cellular \& Developmental Biology - Plant, vol. 27, no. 2, p. 64-69. [CrossRef]

\section{How to cite this article:}

MILOŠEVIĆ, S.; SUBOTIĆ, A.; BULAJIĆ, A.; DJEKIĆ, I.; JEVREMOVIĆ, S.; VUČUROVIĆ, A. and KRSTIĆ, B. (2011). Elimination of TSWV from Impatiens hawkerii Bull. and regeneration of virus-free plant. Electronic Journal of Biotechnology, vol. 14, no. 1. http://dx.doi.org/10.2225/vol14-issue1-fulltext-5 
Copyright of Electronic Journal of Biotechnology is the property of Pontificia Universidad Catolica de Valparaiso and its content may not be copied or emailed to multiple sites or posted to a listserv without the copyright holder's express written permission. However, users may print, download, or email articles for individual use. 